\title{
New Coal-Fired Plants Jeopardise Paris Agreement
}

\author{
Mikel González-Eguino ${ }^{1,2, *}$, Antxón Olabe and Teresa Ribera ${ }^{3}$ \\ 1 Basque Centre for Climate Change (BC3), 48940 Leioa, Spain \\ 2 Department of Foundations of Economic Analysis, University of the Basque Country (UPV/EHU), \\ 48013 Bilbao, Spain \\ 3 Institute for Sustainable Development and International Relation (IDDRI), 75006 Paris, France; \\ teresa.ribera@sciencespo.fr \\ * Correspondence: mikel.gonzalez@bc3research.org; Tel.: +34-94-4014-690
}

Academic Editor: Tomonobu Senjyu

Received: 17 November 2016; Accepted: 11 January 2017; Published: 24 January 2017

\begin{abstract}
Global greenhouse gas emissions need to peak soon and be reduced practically to zero in the second half of this century in order to not exceed the climate targets adopted in the Paris Agreement. However, there are currently numerous coal-fired power stations around the world at different stages of construction and planning that could be completed in the next decade. If all these plants are actually built, their expected future emissions will make it very difficult to reach these targets, even in an optimistic scenario with the deployment of carbon capture and storage technologies. Policy makers around the world need to react quickly and help to redirect investment plans for new coal-fired power stations towards low-carbon technologies.
\end{abstract}

Keywords: Paris Agreement; mitigation; coal plants; $\mathrm{CO}_{2}$ commitment; carbon budget; Carbon Capture and Storage (CCS)

The main objective of the Paris Agreement [1], which came into force on 4 November 2016, is to ensure that the average global temperature increase does not exceed the threshold of $1.5^{\circ} \mathrm{C}$ or $2{ }^{\circ} \mathrm{C}$ above preindustrial levels. For this to be achieved, greenhouse gas emissions need to peak as soon as possible and then be reduced practically to zero in net terms in the second half of this century. This will require that fossil fuels be gradually phased out of the energy mix, especially coal, which is the most $\mathrm{CO}_{2}$-emission-intensive fuel of all in terms of energy content [2].

In spite of the goal set by the international community in Paris, there are still numerous coal-fired power stations currently under construction [3,4]. Between 2010 and 2015, around 500 coal-fired plants were built globally, with a joint output of 473 Gigawatts (GW), a $25 \%$ increase in total power capacity [4]. Countries such as the USA substantially reduced the number of plants operational in that period but others, such as China and India, greatly increased their stock. Moreover, even more new coal-fired stations (see Figure 1) are currently at different stages of construction and planning. Although some of these projects may still be canceled, such as in the case of China where emissions from coal have achieved a peak according to some authors [5], a large part of them could also be finished within the next decade.

If all the plants currently planned are actually built and become active, their expected future emissions will make it very difficult to reach the targets set in the Paris Agreement. The carbon budget available for limiting temperature increases to less than $2{ }^{\circ} \mathrm{C}$ (with a likelihood of $66 \%$ ) is estimated [6] to be $1000 \mathrm{GtCO}_{2}$ from 2011 onwards $\left(400 \mathrm{GtCO}_{2}\right.$ for the goal of $1.5^{\circ} \mathrm{C}$ ). Emissions from 2011 to 2015 totalled $175 \mathrm{GtCO}_{2}$ and, therefore, the carbon budget currently available is $825 \mathrm{GtCO}_{2}$ (and $225 \mathrm{GtCO}_{2}$ for the goal of $1.5^{\circ} \mathrm{C}$ ). Based on an average lifetime of 30-50 years, the cumulative emissions from existing and planned plants (see Figure 2, left-hand panel) add up to $287-569 \mathrm{GtCO}_{2}$, which leaves very little margin for other energy infrastructures [7-9]. Indeed, emissions from plants already in 
operation would suffice to exceed the limit of $1.5^{\circ} \mathrm{C}$, which guarantees that phase-outs before the end of their useful lifetimes and/or the use of carbon capture and storage (CCS) technologies will be required.

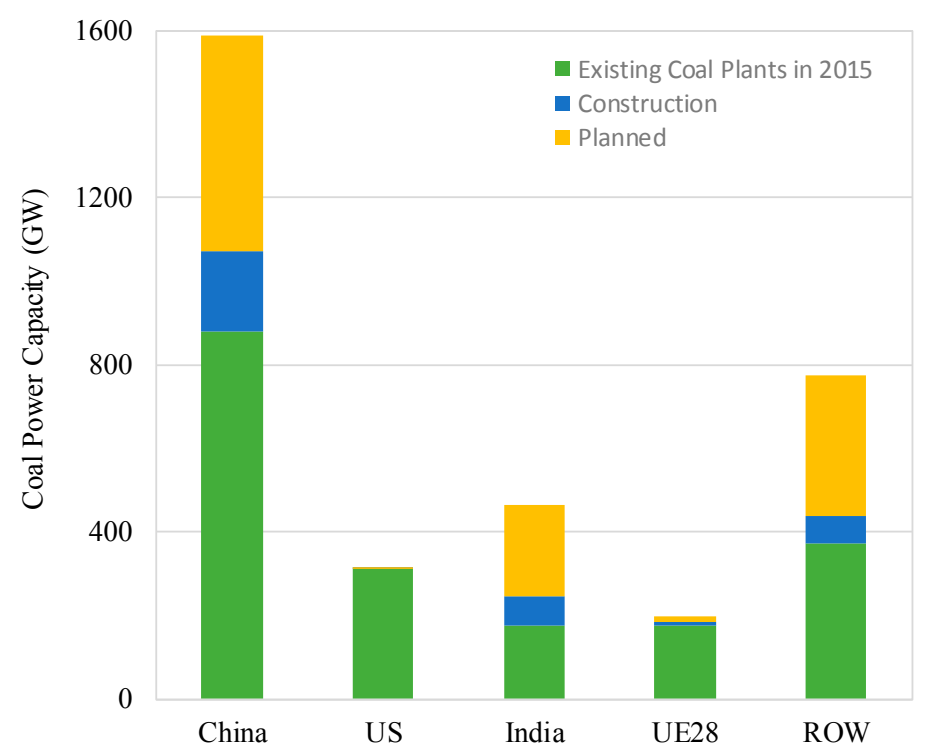

Figure 1. Existing coal power plant capacity in 2015 (green), under construction in 2016 (blue) and planned (yellow) based on [4].

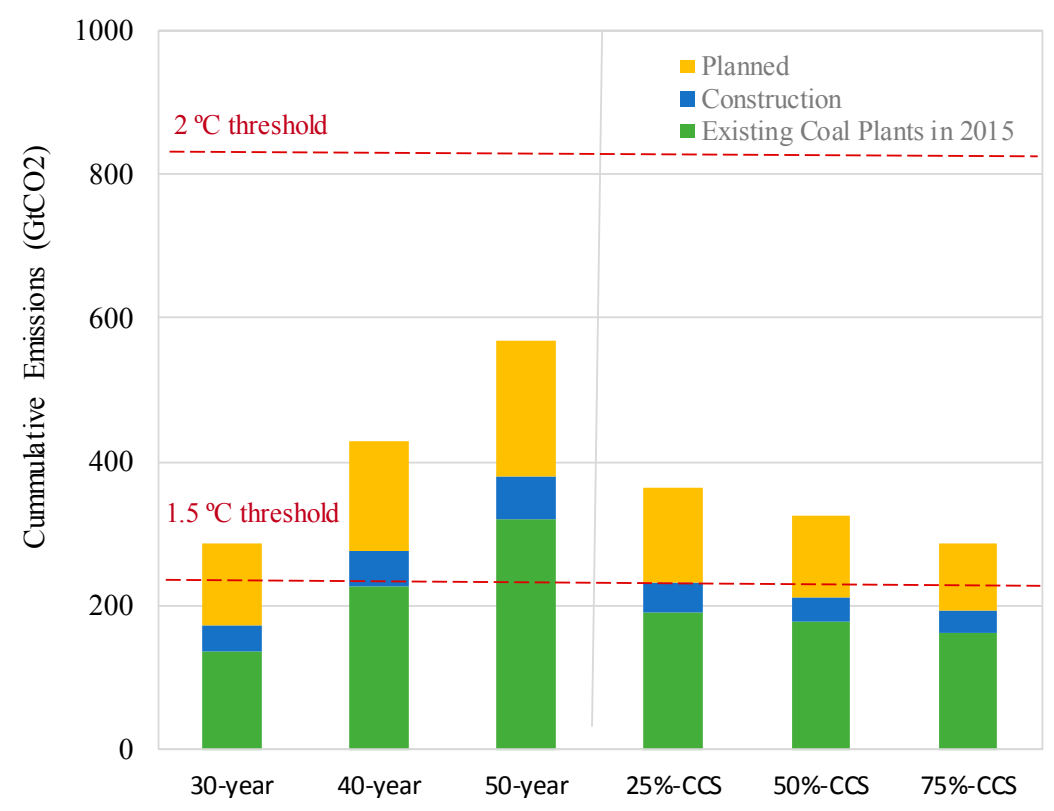

Figure 2. Global cumulative $\mathrm{CO}_{2}$ emissions from existing coal power plant capacity in 2015 (green), under construction (blue) and planned (yellow) with and without Carbon Capture and Storage (CCS). The left-hand panel considers scenarios without CCS for different lifetime scenarios (30, 40 and 50 years). The right-hand panel considers different scenarios where $25 \%, 50 \%$ and $75 \%$ of all coal plants install CCS units in 2030 (for a lifetime of 40 years). $\mathrm{CO}_{2}$ emission factors from existing coal plants amount to $1000 \mathrm{gCO}_{2} / \mathrm{Kwh}$, for new coal plants the figure is $800 \mathrm{gCO}_{2} / \mathrm{Kwh}$ and for coal plants with CCS it is $150 \mathrm{gCO}_{2} / \mathrm{Kwh}$ [10]. The global average age of currently operating coal plants is 15 years. The plant utilization rate considered is $50 \%$ (although it is currently $58 \%$, it is expected that it will decrease with the increasing capacity of renewables). The red lines capture the carbon budget thresholds from 2015 and for the 1.5 and $2{ }^{\circ} \mathrm{C}$ targets with a $66 \%$ likelihood: $225-825 \mathrm{GtCO}_{2}$. 
In theory, CCS could reduce future emissions, but according to the last report of Intergovernmental Panel of Climate Change (IPCC) in 2013 [10], it has not been applied at the scale of a large, operational commercial fossil fuel power plan, so its future availability is still highly uncertain. Moreover, even if the new coal-fired plants currently on the drawing board were hypothetically fitted with CCS systems, their emissions over the course of their life cycles would not be zero but between 90 and $250 \mathrm{gCO}_{2} / \mathrm{Kwh}$ [10]. In a very optimistic scenario, in which $75 \%$ of all coal-fired plants worldwide are assumed to have fitted CCS units in 2030 (see Figure 2, right-hand panel), emissions would reach $287 \mathrm{GtCO}_{2}$. CCS could be a key technology for a low-carbon future (especially if "negative" emissions are needed in the future [11]), but it seems unwise to continue building new coal-fired power plants without first confirming its technical viability at a large scale and also its financial viability compared with other alternatives.

Building new coal-fired power plants not only jeopardises the Paris Agreement but also entails great financial risk for investors, as these plants could also end up being under-used [4]. This is actually already happening in China [12], where the average operating time of coal-fired plants dropped from $60 \%$ in 2008 to $49 \%$ in 2015 and in India where dropped from $78 \%$ to $65 \%$. Regulators and insurers in several countries are warning of how risky these assets are and are recommending rapid disinvestment (California's regulator is a case in point). The potential legal liability of insurers for having under-assessed these risks is even beginning to be mentioned [13]. As a result of these factors, in recent years, there has been a big increase in announcements of disinvestment by major institutional funds such as the Swedish pension fund AP2 and the Norwegian sovereign fund. However, the impact of these actions has been uneven. A large fraction of these investments is state-owned and therefore is harder to pressure from the investors. Direct subsidies for fossil fuels totalled US $\$ 233$ billion in 2014, four times more than subsidies for renewables [14], and half the subsidies provided for coal are still concentrated in the European Union [14]. There are also indirect flows [15] through financial guarantees, export credits and other mechanisms that make it very hard to quantify the public-sector support effectively associated with coal.

In short, there are still contradictory signs at international level in regard to the extent of the decarbonisation of the economy associated with the Paris Agreement [11,15-17]. If a path compatible with the goals set in Paris is to be consolidated, there is an urgent need for a clear policy of support for alternative energy sources. The experience of China between 2000 and 2015 shows that if the great demographic and economic powers base their energy development on the large-scale use of coal, then the mitigation efforts of other countries will be largely cancelled out [18]. Although India plans to have nearly $60 \%$ of its electricity capacity from non-fossil fuels by the next decade, the consumption of coal is projected to grow by $50 \%$ [19]. It is therefore important to react quickly and redirect existing plans for new coal-fired power stations towards technologies compatible with a low carbon future. Accordingly, it is essential that there should be greater transparency in regard to existing funding flows in support of coal, and also that economic aid should be consolidated for countries which have a pressing need to increase their energy consumption.

Acknowledgments: This study received funding from the European Union's Horizon 2020 research and innovation programme under grant agreement No. 642260 (TRANSrisk project). Mikel Gonzalez-Eguino also acknowledges financial support from the Ministry of Economy and Competitiveness of Spain (ECO2015-68023) and the Basque Government (IT-799-13).

Author Contributions: All authors were involved in designing the research, analysing the results and writing the manuscript. Mikel González-Eguino performed the computations and scenarios.

Conflicts of Interest: The authors declare no conflict of interest.

\section{References}

1. United Nations Framework Convention on Climate Change (UNFCC). The Paris Agreement (FCCC/CP/2015/ L.9/Rev.1). 2015. Available online: http://unfccc.int/resource/docs/2015/cop21/eng/109r01.pdf (accessed on 23 January 2017). 
2. International Energy Agency (IEA). World Energy Outlook 2015; International Energy Agency: Paris, France, 2015.

3. CoalSwarm Global Coal Plant Tracker. 2016. Available online: www.endcoal.org/global-coal-plant-tracker (accessed on 23 January 2017).

4. Shearer, C.; Ghio, N.; Myllyvirta, L.; Yu, A.; Nace, T. Boom and Bust 2016. Tracking the Global Coal Plant Pipeline; CoalSwarm, Sierra Club and Greenpeace: San Francisco, CA, USA, 2016.

5. Qi, Y.; Stern, N.; Wu, T.; Lu, J.; Green, F. China's post-coal growth. Nat. Geosci. 2016, 9, 564-566. [CrossRef]

6. Intergovernmental Panel on Climate Change (IPCC). Climate Change 2014: Synthesis Report; Contribution of Working Groups I, II and III to the Fifth Assessment Report of the Intergovernmental Panel on Climate Change; Core Writing Team, Pachauri, R.K., Meyer, L.A., Eds.; IPCC: Geneva, Switzerland, 2014; p. 151.

7. Davis, S.J.; Caldeira, K.; Matthews, H.D. Future $\mathrm{CO}_{2}$ Emissions and Climate Change from Existing Energy Infrastructure. Science 2010, 329, 1330-1333. [CrossRef] [PubMed]

8. Davis, S.J.; Socolow, R.H. Commitment accounting of $\mathrm{CO}_{2}$ emissions. Environ. Res. Lett. 2014, 9, 084018. [CrossRef]

9. Pfeiffer, A.; Millar, R.; Hepburn, C.; Beinhocker, E. The ' $2{ }^{\circ} \mathrm{C}$ capital stock' for electricity generation: Committed cumulative carbon emissions from the electricity generation sector and the transition to a green economy. Appl. Energy 2016, 179, 1395-1408. [CrossRef]

10. Intergovernmental Panel on Climate Change (IPCC). Climate Change 2014: Mitigation of Climate Change; Contribution of Working Group III to to the Fifth Assessment Report of the Intergovernmental Panel on Climate Change; Cambridge University Press: Cambridge, UK, 2014.

11. Kevin, A. Duality in Climate Science. Nat. Geosci. 2015, 8, 898-900.

12. Green, F.; Stern, N. China's changing economy: Implications for its carbon dioxide emissions. Clim. Policy 2016. [CrossRef]

13. Covington, H.; Thornton, J.; Hepburn, C. Global warming: Shareholders must vote for climate-change mitigation. Nat. News 2016, 530, 156. [CrossRef] [PubMed]

14. Coady, D.; Parry, I.; Sears, L.; Shang, B. How Large Are Global Energy Subsidies? IMF Working Paper; International Monetary Fund: Washington, DC, USA, 2015.

15. Natural Resources Defense Council (NRDC). Swept under the Rug: How G7 Nations Conceal Public Financing for Coal around the World; Natural Resources Defense Council: New York, NY, USA, 2016.

16. Rogelj, J.; Den Elzen, M.; Höhne, N.; Fransen, T.; Fekete, H.; Winkler, H.; Schaeffer, R.; Sha, F.; Riahi, K.; Meinshausen, M. Paris Agreement climate proposals need a boost to keep warming well below $2{ }^{\circ} \mathrm{C}$. Nature 2016, 534, 631-639. [CrossRef] [PubMed]

17. Geden, O. The Paris Agreement and the Inherent Inconsistency of Climate Policymaking. Wiley Interdiscip. Rev. Clim. Chang. 2016, 7, 790-797. [CrossRef]

18. Edenhofer, O. King Coal and the queen of subsidies. Science 2015, 349, 1286-1287. [CrossRef] [PubMed]

19. Government of India. Draft National Electricity Plan; Ministry of Power: New Delhi, India, 2016. 